\title{
有機化学の情報化 一現状と将来展望一
}

\author{
中 山伸 -*・吉 田 政 幸*
}

\section{Inclining toward Intellectural Organic Chemistry.}

- Present and Future States -

\author{
Shin-ichi NaKaYAma * and Masayuki Yoshida*
}

\begin{abstract}
Researches of organic chemistry are now in a great revolution, which is aroused by the followings ; ( 1 ) popularization of AI systems for organic chemistry such as synthetic design systems and structure analysis ones, ( 2 ) laboratory automation, and ( 3 ) changes in social consciousness. This article discusses the contents of the present revolution as well as the directions of the future one.
\end{abstract}

\section{解説}

現在，有機化学の研究は大きな変革の時期にある。変 革は, (1) 合成経路設計システムや構造決定システム のような人間の頭脳労働の代理機能を持つシステムの普 及,（2）LA 化の進行による情報環境の整備,（3）社 会意識の変化，によってもたらされたものである。本文 では, 現在起こりつつある变革の内容と将来の方向につ いて論じた。

\section{1．情報化とは何か}

このところ超伝導材料開発のニュースが新聞紙上を賑 わしているが，今から二十年ほど前には情報が世にもて はやされていた。ところで, 超伝導材料と云えば語の意 味ははっきりしているが, 情報とか情報化, 情報化社会 と云った語の意味は人により様々に解釉され、明確では ない。意味が曖昧だからと云って日常的には何の支障も ないが, 有機化学の情報化を論じるにあたっては, 情報 化の意味をある程度はっきりさせておくことが必要であ ろう。それには，情報の意味を明確にしてから情報化の 意味を考えるのも一つの方法であるが，ここでは別のア プローチをしてみよう。

情報化と云う語は様々な使われ方をする。例えば, 「工場やオフィスの情報化が進んでいる」と云うように 使われる。この場合, 情報化とは一義的には工場やオフ ィスへのコンピュータの導入を意味し，二義的にはそれ

*図書館情報大学

* University of Library and Information Science
による生産性や事務処理の効率化, 省力化, 自動化, 作 業内容の精密化を指すものである。やや一般的に表現す るなら, 情報化とは, コンピュータの導入によって人間 が使用する機器の機能を高度化し, 人間のローカルで直 接的な活動の代理機能の向上を図ることと捉えられる。

さて, 情報化と云う語は, 「通信技術が発達し, 通信 施設が整備された社会を指して，情報化が進んでいる」 と云うように使われることもある。この場合の情報化と は, 情報インフラストラクチュアが整備され, 社会シス テムの利用が盛んになり，情報の流通が活発な状況を指 すものである。云うならば, 情報化とは情報の社会的環 境の変化を指すものと捉えられる。

上記の二つの意味での情報化が進めば，人々の知的関 心が拡大し，情報に対するかかわり方や意識も変わって くる。それとともに人間の価值観などの社会意識や産業 のパラダイムも大きく変わる。このような現象を指して 情報化という場合もある。

このように情報化と云う語は大よそ三通りの意味に使 われている。そこで, 有機化学の情報化も研究活動, 情 報環境, 研究価值観の視点から眺め, その現状と将来の 展望を探ってみよう。

\section{2. 研究活動の情報化}

2.1. 実験労働の情報化 日常の研究は大別して二つ の要素から成立している。即ち, 日常の実験労働と問題 解決のための頭脳労働である。情報化を実験労㗢の効率 化, 省力化, 自動化, 内容の高度化と捉えると, 有機化 学の研究の情報化は, 実験の各ステップにおける機械 化, 自動化技術の向上と密接にかかわっている。例え ば，NMR についてみると，多核種 NMR や $400 \mathrm{MHz}$ 超 
高分解能 NMR などの普及, 二次元 NMR 法の導入によ り, 物質の構造についてのより詳細な情報が得られるよ うになってきた。それはとりもなおさず，実験労働の内 容の高度化を意味しているものと理解される。また, 多 重掃引のおかげで, 測定に要する試料もごく小量で充分 になった。小量の試料の分離, 生成はクロマトグラフ イーによって自動的に行うことができる。その結果，実 験のスケールは小さくなり, 実験の時間も大幅に短縮さ れ，実験労働も省力化されつつある。

この種の情報化は分離, 分析技術の向上によってもた らされている。それに対して, 有機合成の基本的操作で ある加熱, 攪はん, 添加, 抽出, 再結晶, 蒸留などの技 術の進歩はそれほどでもない。合成プロセスをシステム 化し, 自動化する研究もあまり進んでいない。研究が最 先端までくれば, プロセスのコントロールを機械だけに まかせるわけにはいかないが, いつでも最先端にいるわ けではない。日常の研究では既知試料の調製に多くの時 間がとられているのも事実である。このような現状をみ ると, 合成プロセスの自動化を真剣に考える時期にきて いるのではなかろうか。

2.2. 頭脳労働の情報化 有機化学の研究において, 研究者は構造決定や合成経路設計など解決しなくてはな らない問題にしばしば遭遇する。研究者はこれまでこの ような問題の解決に頭脳を使ってきた。ところが最近で は, 人間のこのような頭脳労働の代理機能をもつシステ ムが種々開発されている1)。本特集の主旨はこのような システムの解説である。個々のシステムの詳しい内容は 各解説を見ていただくとして，ここではその概略を述べ ておく。

すでに市販されていたり, 公衆回線によりアクセスで きたり，大学などの大型計算機センターで簡単に使える その種のシステムとして, 合成経路設計システム, 構造 決定システム，分子設計システムなどがある。合成経路 設計システムは，合成目的物を設定したときに，それを 合成する経路を設計するシステムである。システムに は，既知反応の組み合わせで設計するものと，理論的に 行うものとがあり, 前者を稼動させるためには反応を覚 えさせてやる必要がある。構造決定システムはスペクト ルデータなどから部分構造, 平面構造, 立体構造を推定 するシステムである。最近では各種の分析機器のデータ をオンラインで取り込み構造決定する総合分析システム もつくられている。分子設計システムは化合物の構造か ら薬理活性, 物性, 反応性を予測したり, 平面構造から 立体構造を計算するシステムである。構造活性相関解 析, 分子軌道計算, 分子力学計算はこのシステムのサブ
Table 1 AI systems for organic chemistry.

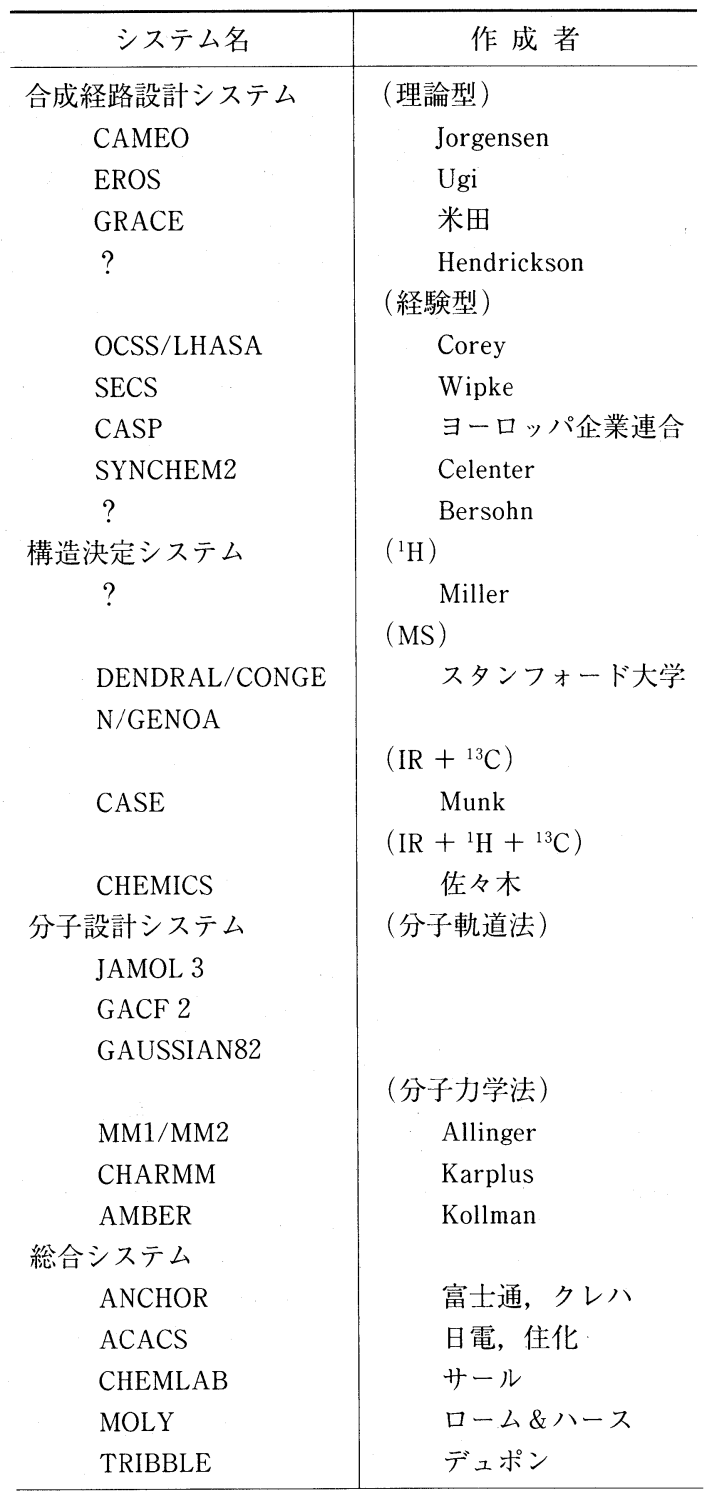

システムに位置付けられる。もちろんそれらのシステム を有機的に結びつけた統合システムもある。主要なシス テムを表 1 にあげておく。

これ以外にも高分子設計システム, 実験に直接関係す るものとしてクロマトカラム選択システム, 触媒選択シ ステムなど多数の頭脳労働の代理機能をもつシステムが 開発されている。

ところで, 有機化学の研究で頭脳を使うのは合成や構 造決定, 実験ばかりではない。ハメット則の発見のよう に, 物性や生理活性などの観測值と構造の関係を解析 
し, 経験式を作り, 関係の本質を追求するのも研究の大 きな目的の一つである。これまで有機化学者は，この様 な関係を直感的に発見してきたが，観測される現象が 様々な要因からなる場合は関係の発見は困難である。こ のような場合に多変量解析やパタン認識の手法が役立つ が, 残念ながら有機化学者のこれらの手法に対する関心 は低い。

以上に述べたように, 人間の頭脳労働の情報化は着々 と進んでいる。とは云うものの, 個々のシステムはまだ まだ完全ではない。また，作るべきシステムもまだまだ 多数ある。例えば, これまでのシステムの多くは, 構造 を入力してやるとそのもののスペクトル, 物性, 生理活 性などを予測するが，その逆に性質から構造を創出する ことはできない。このような場合，人間ならそのような 性質を持つ化合物を検索し, 次にこれまでに得た経験や 知識から性質一構造の関係を分析し, 新しい構造を考え だす。このような思考プロセスをシステム化した人工知 能システムも今後は構築されるであろう。そうなると, どのような性質を持つ化合物を合成すべきかということ が有機化学の主要な問題になるであろうし，またそうな れば化学の教育の内容も変わってくるであろう。

\section{3. 情報環境の変動}

3.1. オンライン情報検索 有機化学者の情報環境 は，文献情報やファクト情報に関するデータベースの整 備とそれらを利用するためのオンライン情報検索システ ムの普及により大きく変わりつつある。

有機化学者は通常, 研究関連分野の論文誌に定常的に 目を通し, 関連分野の最新の情報を得ている。CA

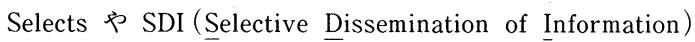
サービスの利用も広がりつつあるが，論文誌が情報入手 の主役であることには変わりがない。

あるテーマについて研究を始めるときとか, 研究が完 了したときには，そのテーマに関する情報を現在から過 去にさかのぼって徹底的に調查する必要がある。従来, このような調査はケミカルアブストラクッ $(\mathrm{CA}) を$ を使っ て行われていたが, 最近ではオンライン情報検索による 調査が一般化している。オンラインによる検索では AND， OR などのロジック検索が可能であり，検索した 文献の複写依頼も出来るなど大変便利である。検索結果 を端末のパーソナルコンピュータのファイルにダウン ロードすれば，必要なときにいつでも引き出せる。シス テムによっては部分構造式による検索も出来るし, 文献 の抄録もその場でみられる。このようなオンライン情報 検索システムの出現により文献調査の能率は一段と上が
ったが，現在の文献検索方式は必ずしも完全ではない。 有機化学者がしばしば必要とする情報の一つに, 反応 や合成についての情報がある。反応や合成そのものを研 究対象とした論文中に記載されているこれらの情報は, 文献検索で抽出されるが，それ以外の論文にある反応や 合成についての情報は，これまでの文献検索では探すこ とができない。そこで，これらの情報だけを特別に収集 し，データベース化した反応データベースが作成され， 公開されている。また，米国のケミカルアブストラクト サービス（CAS）でも最近, 反応を構造, 部分構造, CAS 登録番号で指定したり, 試薬, 生成物, 反応物, 溶媒などを指定して検索するサービスを開始する予定で ある。

一般に文献検索の効率は呼び出し率（検索された目的 の文献総数/目的の文献数) と適合率 (=検索された目 的の文献総数/検索された文献総数)によって計られ る。およそ70 万件の生物医学文献からなる Medlars データベースを用い，300 の質問について呼び出し率と 適合率が吟味されている2)。それによると，これらの值 は質問の内容によって変わる。呼び出し率と適合率の間 には，呼び出し率が上がる(0.89) と適合率が下がり (0.20)，その逆に適合率が上がれば $(0.80)$ 呼び出し率 は下がる（0.19）という関係がある。300の質問につい ての呼び出し率, 適合率の平均值は, それぞれ 0.58 , 0.50 である。化学文献の検索でも事情はあまり変わら ないであろう。とすると, 我々は知らないうちに, 多数 の重要な文献をミスしていることになる。文献を少数の キーワードで代表させている現在のシステムでは，この ようなトラブルが起こるのも当然である。それを防ぐ方 法として, 全文データベースシステムが検討されてい る。

全文データベースとは文献の書誌事項ばかりではな く, 本文の全てが収録されているデータベースである。 このシステムでは, 副詞, 冠詞, 数詞, 前置詞, 代名詞 などの特別な語以外は文献中に現れる全ての自然語を キーワードとして検索できる。化学文献では内容の範囲 がある程度限られ，使用される語もかなり限定されてい るので, 呼び出し率は上がる。さらに, 検索しながら必 要な文献の本文が読めるので, 化学者にとって有力な道 具となるであろう。現在, アメリカ化学会が代表的論文 誌の全文データベースを提供している3)。論文誌の全文 データベースによる提供が増え，それらがネットワーク 化される日も近いであろう。

有機化学者はこれまで, 物質の同定, 確認のために データブックを用い, 物質名や構造式からスペクトル 
データや物性データを調べてきた。そのために種々の データブックが用意されているが，それらを用いてスペ クトルデータや物性データから物質名を同定したり，関 連物質を検索するのは難しい。ファクト情報が冊子体で 蓄積されている以上仕方がないことであるが, デー夕 ベース化しておけば多面的な検索が可能になる。さら に，種々のスペクトルデータベース，熱力学的物性デー 夕ベース，毒性データベースなどの各ファクトデー夕 ベースを化合物辞書で結び付ければ，各種ファクトデー タベースの複合検索が可能になる。実際このようなシス テムがCIS（Chemical Information System）から提供さ れている（図1)。

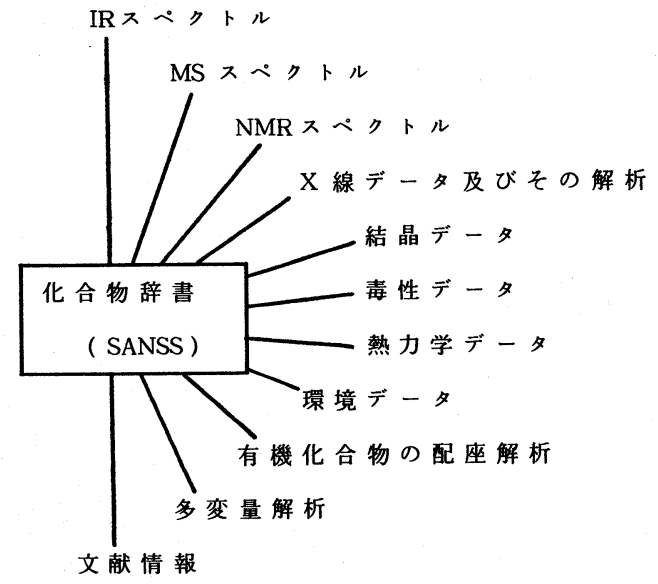

Fig. 1 Architecture of CIS systems.

有機化学関連の主要データベースを参考までに表 2 に あげておく。

3.2. 情報のローカル処理 オンライン情報検索は便 利な道具として広く利用されている。ところで,これを 実際に使用してみると，検索結果を見ながら次にどうす るか落ち着いて考える余裕がない。それと云うのも，検 索に要する時間が検索費用に加算されるからであろう。 それはさておき，大局的な観点に立って考えると，情報 の集中管理はシステムの脆弱性，情報の支配の面から望 ましくない。システムの分散化による情報のローカルな 処理が今後の情報化の方向であろう。その動きは具体的 にマイクロコンピュータや CD-ROM の普及に見ること ができる。

現在, 多くの化学研究室にマイクロコンピュータが導 入されている。これらはオンライン情報検索の端末や ワープロ，数值計算に使われるほかに，実験内容などの パーソナルデータベースの構築にも利用されている。企 業の研究所の中には研究所ぐるみで実験ノートや報告書
Table 2 Major data-bases for organic chemistry.

\begin{tabular}{|c|c|c|}
\hline $\begin{array}{l}\text { デー夕 } \\
\text { ベース名 }\end{array}$ & 内谷 & プロデューサ名 \\
\hline \multicolumn{3}{|c|}{ 文献データベース } \\
\hline $\begin{array}{l}\text { CA } \\
\text { SEARCH }\end{array}$ & 化学全般 & CAS \\
\hline $\begin{array}{l}\text { CAS } \\
\text { ONLINE }\end{array}$ & 構造検索, 抄録 & CAS \\
\hline CRDS & 有機合成反応 & Dewent Publ. Ltd. \\
\hline ISI-IC & 同上 & ISI \\
\hline CLAIMS & 特許 & IFI/Plenum Data Cmp \\
\hline INPADOC & 同上 & Int. Pat. Doc. Cent \\
\hline JAPATIC & 同上 & JAPIO \\
\hline \multicolumn{3}{|c|}{ ファクトデータベース } \\
\hline ID-IR & IR スペクトル & 旭化成 \\
\hline IRSS & 同上 & NIH/EPA, KIBK \\
\hline IR-SPAN & 同上 & 三菱化成 \\
\hline SPECTRA & マススペクトル & NBS, NIH/EPA \\
\hline MSSS & 同上 & NIH/EPA, MSDC \\
\hline C13NMR & ${ }^{13} \mathrm{CNMR}$ & BASF AG \\
\hline CNMR & 同上 & NIH/EPA, NIC \\
\hline HEILBRON & 物性デー夕 & Chapman \& Hall Ltd. \\
\hline PPDS & 同上 & ICE \\
\hline DERMAL & 薬理データ & EPA, OTS \\
\hline RTECS & 毒性データ & $\mathrm{NIH}$ \\
\hline TOXLINE & 同上 & NLM \\
\hline \multicolumn{3}{|c|}{ 全文データベース } \\
\hline CFTX & ACS の論文誌 & ACS \\
\hline \multicolumn{3}{|c|}{ 化合物辞書データベース } \\
\hline CHEMNAME & 化合物辞書 & CAS \\
\hline EURECAS & 同上（構造可） & CAS \\
\hline SANSS & 同上 & NIH/EPA \\
\hline
\end{tabular}

のデータベース化を進めているところもある。最近では マイクロコンピュータが組み込まれた分析機器の普及 で，ファクトデータが電子的に取り扱えるようになり， フロッピーベースでスペクトル情報を自分のマイクロコ ンピュータに取り込むこともできる。普段の実験ノート やこのように取り込んだデー夕は電子的に様々な処理が 可能である。処理したデータとワープロ機能がつなげれ ば報告書などの作成が効率的に行えるであろうし，昔や ったことが報告書や実験ノートの検索により容易に引き 出せるようになるだろう。

CD-ROM は一枚のディスクに記憶された膨大な量の 情報を検索できるシステムで，このところ出版業界が普 及に熱を入れている。これらは通常の情報検索システム と同等の機能を有しており, 中には全文データベースの 
機能までをも取り込んでいるものもある。一年分の特許 情報, Org. Synth.などを入力したディスクがすでに市販 されている。今後, 論文誌, CA, バイルシュタイン, 有機化合物事典, 物性デー夕集, スペクトルデー夕集な どが収録された CD が市販されれば，情報の利用が一段 と活発になるであろう。

個人的なことはパーソナルデータベースを，公的なこ とはCD-ROM を使ったデータベースをそれぞれうまく 使えば，かなりのことがローカルに処理できるようにな る。自分が持っているシステムなら，いくら時間をかけ ても通信費はかからず，研究者は検索などの処理をじっ くり考えながら行うことができよう。

\section{3. ネットワーク化の動き 中央集中型のコンピ} エータをTSS で利用するのは, 通信費用やシステム維 持などの点で問題がある。かと云って各研究者が完全に 独立のシステムを持ってしまうと云うのも考え物であ る。個人が作成できるデータベースなどは高々知れたも のであるし, CD-ROM のような形で提供されるデータ ベースなども個人で購入するには高価である。比較的高 機能のワークステーションをローカルエリアネットワー ク（LAN）でつないだシステムは，上記の両システム の中間的なものとして考えられる。各研究者はそれぞれ のワークステーション上で情報を作成し，その中に蓄積 すれば，他の研究者はネットワークを介してそれらの情 報を使うことができよう。

情報をこのような形で共有化できるようになったら， 実験ノートをワークステーション上で直接作って行くこ とが推奨されるだろう。報告書や論文に書ききれない実 験デー夕や論文作成に至らなかったネガティブなデー夕 までもが公表されれば，そのLANにつながる研究者の 研究効率の向上に役立つ。もちろん，そうするためには 検索し易い形で実験ノートを作成する必要がある。ま た,この LAN に種々の計測機器などをつなげば, 研究 所内の LA 化が実現する。研究者は自分の机の上から各 種の機器を制御し、データをオンラインで得ることがで きよう。

現在, 情報収集はオンライン情報検索のお陰でずい分 効率的になってきた。しかし，今使えるオンライン情報 検索の多くは，大規模デー夕ベースを対象としたもので あり，一般的な情報や特殊な情報の収集には依然として 図書館の利用が必要である。この様な状況も LANを介 してレーザーディスクや CD-ROM などが使えるように なれば改善される。Annual Roports や Specialists Periodical Reports 等の図書館にしかないような本が CD-ROM などに収録されれば，研究者はいながらにし
てそれらを見ることができる。もちろん，それらは全文 データベース的な使い方ができるだろうし，必要なとこ ろは自分のファイルにコピーしたりハードコピーを取っ たりできるだろう。これが電子図書館の姿である。

電子図書館は研究者が図書館に行く労力を無くしてく れると共に, 自分の手元に置いておく図書も無くしてく れ, 省スペース化や本の重複購入の無駄を省くのにも寄 与するだろう。

さらに一歩進めば，各々の LAN を電話回線などを介 して相互に結ぶこともできる（図 2 )。そうなれば一台 のワークステーションで他の LAN 内に流通している情

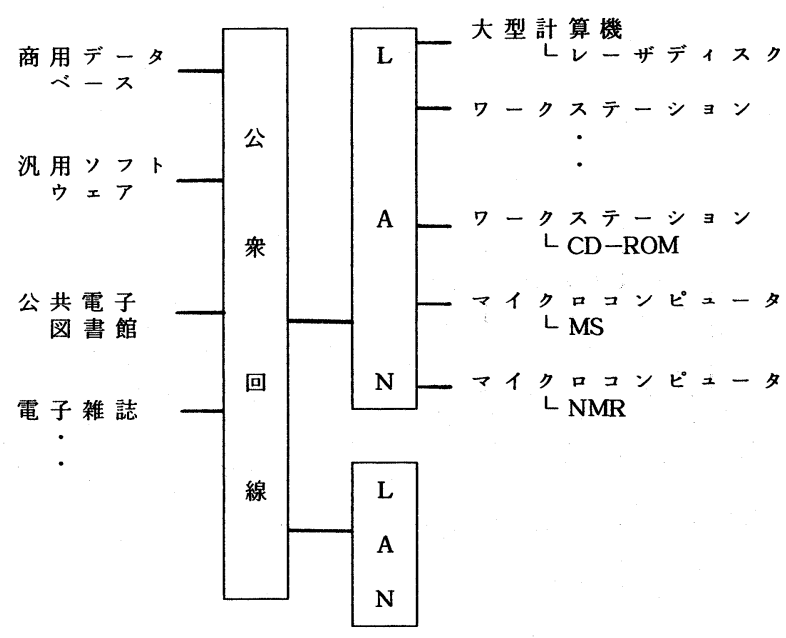

Fig. 2 Future information environments for researches of organic chemistry.

報を引き出したり, 各種のオンライン情報検索へのアク セスができる。そのような環境が充実してくると, 電子 雑誌の構想が実現化してくる。

現在, 多くの研究者がワープロを使って論文を作成す るようになってきた。ワープロの持つ文書作成環境は手 書きによるものに比べて効率的である。ワープロを使っ て作成した論文は，そのまま回線を使って他の人に送る ことができる。電子雑誌のシステムでは，まず著者がこ のように回線を使って論文を編集者に送る。編集者はレ フリーにそれを送って審査を依頼する。そしてレフリー が賛成すれば論文を公表用のファイルに入れる。読者は そのファイルを雑誌のかわりに見るというものであ る4。

電子雑誌のシステムでは, 論文の流通までの時間が短 縮される利点がある。雑訫の講読者にとっては, 雑誌を 手元におかなくて済む利点もある。J. Org. Chem. や 
J. Am.Chem. Soc.の一年分はだんだん膨大になってきて おり, 雑誌の重みで床が抜けるのではないかと危惧して いる購読者も少なくないであろう。電子雑誌になれば, 必要なのはワークステーションだけで, 机の片隅の場所 を占有するだけですむ。

もちろん電子雑誌を全文データベースシステムに載せ ればより使いやすくなる。雑誌のバックナンバーを遡及 的に見返すような作業はコンピュータが一瞬のうちにや ってくれる。そうなると論文をコピーしたり，整理して ファイルを作るというような努力はなくなるだろう。

\section{4. 社会意識の変動とその影響}

テクノロジーの発達による人間の代理機能の向上は, 社会の諸分野においていろいろな形で発現している。企 業活動では, 例えば事業部門の OA 化, 生産部門の FA 化等である。一方, コンピュータと通信ネットワークが 統合して形成される情報化インフラストラクチュアが整 備され，エレクトロニックバイキング，切符予約， CATV,VANなど社会システムも着々と開発されてい る。それにともない, ソフトウェア産業, 情報流通サー ビス業, シンクタンクなどの情報産業も成長している。 産業構造も「重厚長大」から「軽薄短小」へと移行し た。「軽薄短少」はまた, 製品開発のコンセプトでもあ る。製品開発はニーズ志向性が強まり, 製品コストに揖 ける情報の占める割合が大きい, いわゆる高付加価製品 が次々と世に送り出されている。

これらの現象は相互に影響し合い, 社会全体の意識を も変えつつある。その変化が情報化と云われるものであ る。まず, 現代生活の基礎と枠組みとを作る考え方, 生 き方は, 工業時代の非個性化, 平均化から個性化, 多様 化, 分散化へと移行している。工業化がある水準に達 し, マスコミュニケーションにより情報が充分に伝達さ れるようになると, 社会の全員が同じようなものと情報 を入手する。そこから平均化が社会の目標となる。平均 化, 非個性化がさらに進めば，逆に個性的であろうとす る。テクノロジーの発達で多様なニーズに対応した製 品, 情報の提供が可能となり, 個性化, 多様化が社会の 目標となる。多様なものが充足されると, さらに「もの から心へ」の移行があり, 知的関心が高まる。

価值観にも変化が起こりつつある。従来の伝統的価值 観は勤労, 節約, 自己犠牲, 時間厳守など人間の自然的 性情を抑制するものである。人間の代理機能が高度に発 達すると, このような価值観は相対的に低くなり, 新た に健康, 快適, 便利などの人間の自然的性情を満足させ ることに重きを置く価值観が生まれてくる。
事実, 週休 2 日制も定着しつつある。残無デーと称 し, 一週間に一日, 残業無しの日をもうける企業もでて きた。肉体を酷使し、ひたすら㗢くばかりが能ではな い。企業としてはゆっくり休んで, 知的能力を開発して くれと云うわけである。日本生産性本部が行った「新産 業社会一変貌を迫られる日本経営」のディスカッション によると, 経済尺度も従来の GNP（国民総生産）至上 主義から, 将来は精神的満足まで取り込んだ $\mathrm{GNH}$ (Growth National Happiness) に移行し, 企業組織もピ ラミッド型からネットワーク型に変わり, 個人の主体的 行動が重要視されるようになると云うのである。そこに 至る過程として, 経済同友会は, 企業人の姿勢として, 「柔考挑題」を提唱している。「柔考挑題」は「重厚長 大」をもじったものであるが, 与えられた仕事を真面目 にこなすだけの受身ではなく, 柔軟な思考で企業の利益 となるようなアイディアや問題を考え，それに挑戦する 姿勢が望ましいと云う意味である。これは, 現代人の生 き方のスローガンでもある。

人間は誰しも時代に条件付けられ, 支配され, 影響さ れて生きている。その一方で, 時代に働きかけ, 時代を 作っている。ヘーゲルがいみじくも述べたように,「個 人はもともと誰しも時代の子」である。ならば, 有機化 学の研究も, 現代の社会意識である情報化の影響を受け ているはずであろう。事実, 影響の跡が随所に認められ る。

研究の方向について考えてみよう。まず, 高付加価値 製品の開発のコンセプトを受け, ファインケミカル思考 が定着した。多様化, 分散化の流れの中で, 研究の夕ー ゲットも第三, 第四周期典型元素に, また生物学, 農 学, 薬学, 医学などの他の分野にも拡大しつつある。従 来からの微視的で本質的な学問的探求に加え, 医薬, 農 薬の合成のようにニーズに基づく目的研究が盛んであ る。

化学者はこれまで働き者であった。化学の実験室の明 りは夜遅くまでこうこうと輝き, 化学者にとって長時間 にわたって実験をするのが最高の善であった。しかし, 長時間の実験は実験の情報化によって短縮されよう。実 験時間が短縮された分だけ，また実験しても意味がな い。短縮された時間は知的労働に使ってこそ意味があ る。そうなると, 研究のスタイルも,「この天然物から 何か新しい生理活性物質が見つかるかも知れない」式の 発見的研究から,「仮説一演えき-実証」の科学的探求の 研究に移るだろう。そこにおいては，「Aと B を混ぜ, そこにCを加えたら、これまでとは違った D ができる だろう」などの比較的単純な仮説ではなく，より深い考 
えに基づく仮説が要求される。

実験の情報化が極限まで進めば，研究の成果は，何を するか,どのような問題意識を持つかによって決まる。 若年の研究者は, 問題が与えられると, 獲物を追う猟犬 のように問題解決にまい進する。そこで問題解決型の思 考が定着する。ところが, 問題解決思考は人工知能に任 せられるようになる。となると, 問題を発想することが 重要になるが, 残念なことにそのような考えに慣れてい ない。今後は基礎研究でも応用研究でも明確なミッショ ンを持ち, 研究者一人一人がこれまで以上に「柔考挑 題」の姿勢を取ることが要求されよう。

他の科学分野, 例えば建築学の分野では, 何を研究す べきかを社会工学的に研究する建築計画の分野がかなり
以前から誕生している。有機化学にも将来そのような分 野が誕生するであろう。

\section{(昭和 62 年 7 月 13 日受理) \\ 文献}

1) 日本産業技術振興協会, 化学工業の技術開発の情報 化に関する調査（1985）

2) F.W.Lancaster, "Evaluation of the Medlars Demand Search Service", (1968) National Library of Medicine

3) S.W.Terrant, J. Chem. Inf. Comput. Sci., 24, 230 (1984)

4) M.Turoff, S.R.Hilts, J. Am. Soc. Inf. Sci., 33, 195 (1982)

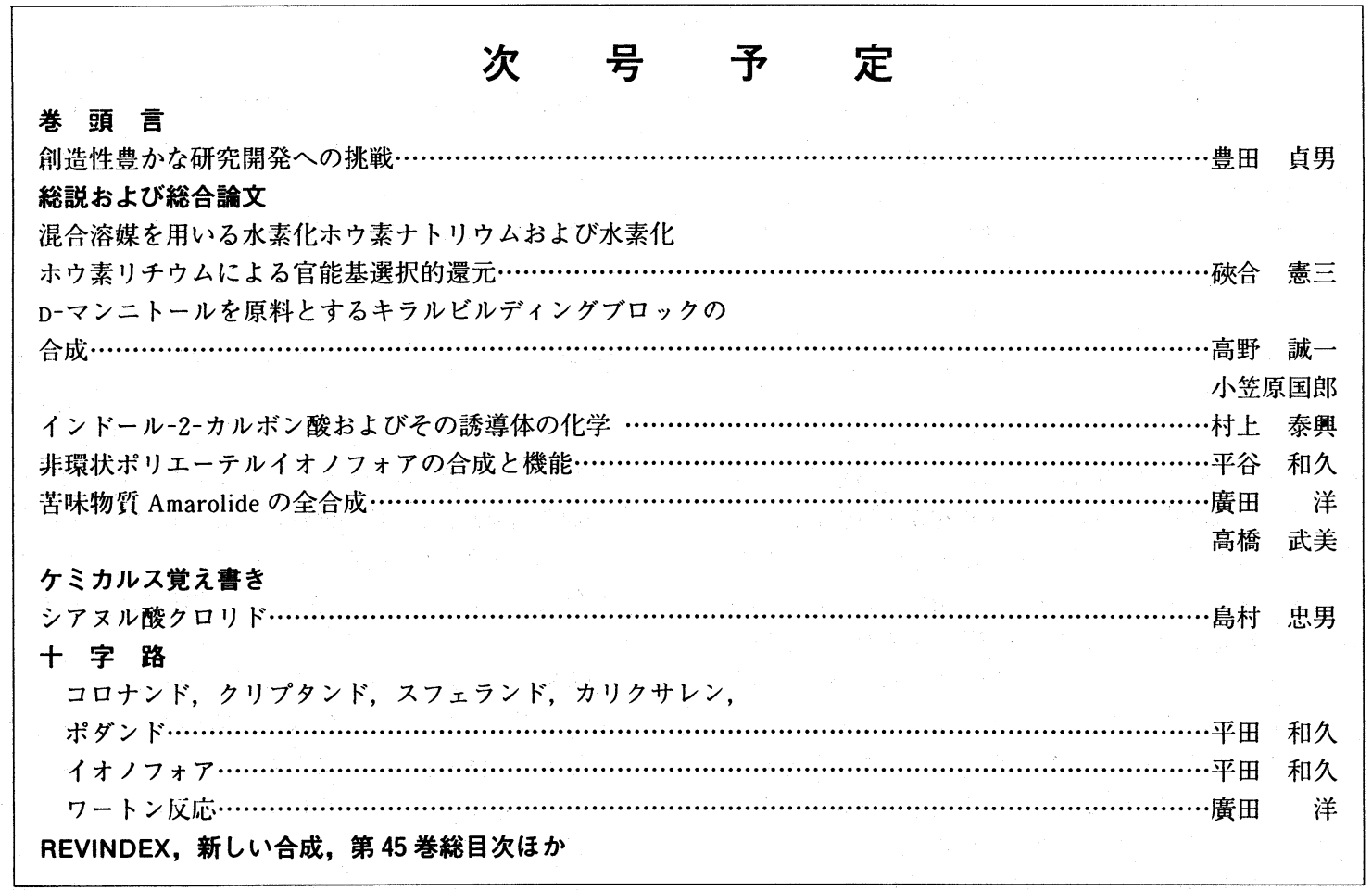

